\title{
PHARMACY
}

\section{СУЧАСНІ ПІДХОДИ ДО РОЗРОБКИ НАНОСИСТЕМ ДОСТАВКИ ЛІКІВ}

\author{
Брубейкер I. O. \\ к.фарм.н., дочент, Кафедра фармацевтичного менеджменту, клінічної фармації, технології \\ ліків, Украӥна, Київ, ПВНЗ «Київський медичний університет», \\ ORCID ID: https://orcid.org/0000-0002-0049-9513
}

Білан О. A.

стариий викладач, Кафедра фармачевтичного менеджменту, клінічної фармачії, технологї ліків, Україна, Київ, ПВНЗ «Київський медичний університет»,

ORCID ID: https://orcid.org/0000-0002-2720-6864

\section{Марченко-Толста К. С.} асистент, Кафедра фармакології, клінічної фармакологї, патофізіології, Україна, Київ, ПВНЗ «Київський медичний університет», ORCID ID: https://orcid.org/0000-0001-7744-5874

\section{DOI: https://doi.org/10.31435/rsglobal_ws/30062020/7102}

\section{ARTICLE INFO}

Received: 10 April 2020

Accepted: 05 June 2020

Published: 30 June 2020

\section{KEYWORDS}

nanopharmacy, nanotechnology, nanodrugs, drug delivery systems, drug targeting, controlled release.

\begin{abstract}
The review investigates the latest developments in the field of application of nanotechnologies in the transportation of therapeutic agents, features and the advantages of using nanoscale drug delivery systems for the treatment of diseases, as well as further prospects of using this field in medicine. Modern drug delivery systems are characterized by target orientation, rapid response to the environment and the use of biocompatible and biodegradable nanomaterials which allow for the development of the next generation of more effective drugs. Interdisciplinary research in this fast-growing field provides opportunities to design and develop multifunctional devices that can accurately target and successfully administer the release and distribution of active ingredients in the body.
\end{abstract}

Citation: Brubaker I. O., Bilan O. A., Marchenko-Tolsta K. S. (2020) Modern Approaches to Development of Nano-Systems for Drug Delivery. World Science. 6(58), Vol.1. doi: 10.31435/rsglobal_ws/30062020/7102

Copyright: () 2020 Brubaker I. O., Bilan O. A., Marchenko-Tolsta K. S. This is an open-access article distributed under the terms of the Creative Commons Attribution License (CC BY). The use, distribution or reproduction in other forums is permitted, provided the original author(s) or licensor are credited and that the original publication in this journal is cited, in accordance with accepted academic practice. No use, distribution or reproduction is permitted which does not comply with these terms.

Вступ. У попередньому огляді [2] ми досліджували останні тенденції в розробці наноліків (nanodrugs); в цій статті продовжимо огляд сучасного стану розвитку нанофармації, а саме, напрямок «нанорозмірні системи доставки ліків» (nanoscale drug delivery systems, nanoDDSs). Це найбільш популярне застосування нанотехнологій в медицині: на частку $D D S s$ припадає $78 \%$ продажів і $58 \%$ заявок на патенти по всьому світові. Дохід від їх виготовлення та продажу лише в 2019 році перевищив 170 млрд. дол., а в 2020-му, як очікується, виросте ще на 20\% [3].

Проектування та синтез ефективних систем доставки лікарських засобів (ЛЗ) мають життєво важливе значення для медицини. Терапевтична успішність ЛЗ багато в чому залежить від здатності діючої речовини потрапити у клітину, для чого їй потрібно здолати в організмі декілька бар'єрів: анатомічні (епітелій, ендотелій, клітинна мембрана), фізико-хімічні та ферментативні. Подолати всі ці бар'єри допомагають «системи доставки ліків». 
Доставка - це спосіб управляти наноліками задля досягнення певного терапевтичного ефекту. Від способу транспортування залежать швидкість поглинання, розподілу, метаболізму і кліренсу наноліків, а отже тривалість їх дії та результативність. В сучасних системах наноматеріали використовуються для контрольованого транспортування терапевтичних агентів до цільових об'єктів на системному, локальному (тканини, органи, окремі клітини) та внутрішньоклітинному рівнях (intracellular delivery), а також для розробки нових формулярів для потужних біоактивних сполук 3 несприятливими характеристиками. Інкапсуляція у nanoDDSs призводить до глибоких змін в розподілі та виведенні ЛЗ, а також у терапевтичній ефективності (досягнення бажаних ефектів і зменшення масштабу несприятливих наслідків).

Мета дослідження. Метою роботи $\epsilon$ дослідження сучасних тенденцій розвитку розроблених на основі нанотехнологій систем, які використовуються для доставки ліків.

Методи дослідження. Аналіз літератури (першоджерел), порівняльний аналіз різних методичних підходів, контент-аналіз текстів.

Результати дослідження. NanoDDSs визначаються як системи доставки ліків 3 наночастками (НЧ) або двофазними ліками, в яких принаймні один вимір розміру дисперсної фази або часток знаходиться в нанометричному діапазоні [7]. Для розробки nanoDDSs використовуються НЧ (як правило <100 нм) синтетичних полімерів, ліпідів або металів, які поглинаються клітинами більш ефективно, ніж макромолекули ліків. Для використання в якості $D D S s$ завдяки високому рівню біосумісності та біоразкладаности ідеально підходять НЧ, виготовлені 3 синтетичних полімерів, таких як полівініловий спирт, poly-l-lactic acid, поліетиленгліколь (ПЕГ), poly(lactic-co-glycolic acid), полімер-ліпідні гібридні НЧ, а також природні полімери, такі як альгінат і хітозан [8].

Загалом процес доставки наноліків можна розділити на 3 етапи:

1) введення препарату - неінвазивним (перорально, місцево - трансдермально i трансмукозально, а також інгаляційно) або інвазивним (ін'єкція або введення через наноігли) способом;

2) вивільнення активного інгредієнту (інгредієнтів);

3) транспортування активних інгредієнтів через біологічну мембрану до місця призначення для виконання цільової дії.

Для розробки сучасних $D D S s$ необхідні міждисциплінарні дослідження, поєднання розробок у фармації, молекулярній біології та органічній хімії, тому що контрольована доставка ліків поєднує фізичні механізми (розчинення, осмос, дифузію і т. д.) та біохімічні (генна терапія, використання ліпосом, моноклональних антитіл, виготовлення мікроемульсій $\mathrm{i}$ т. д.). Під час проектування нових $D D S s$ особливу увагу приділяють діагностиці патологічних станів, фармакодинаміці та фармакокінетиці наноліків. Загалом, для організації ефективної доставки важливо розуміти:

- взаємодію наноматеріалів з біологічним середовищем;

- молекулярні механізми клітинної сигналізації, які беруть участь в патофізіології конкретного захворювання;

- механізми функціонування рецепторів на поверхні клітин, на котрі націлюється nanoDDSs;

- фармакокінетичні характеристики ЛЗ - особливості процесу вивільнення, розповсюдження та метаболізму діючої речовини/активного інгредієнту, а також стабільність і взаємодію кількох ЛЗ при їх одночасному введенні.

Дослідження в області раціональної доставки діагностичних або лікарських засобів допомагають:

a) визначити точні мішені - клітини та рецептори, що пов'язані 3 конкретними клінічними умовами (ключовими мішенями $\epsilon$ мононуклеарні фагоцити, дендритні, ендотеліальні та ракові клітини - пухлини та судин [4]), а також

б) вибрати відповідні наноносії для досягнення необхідних реакцій при мінімізації побічних ефектів.

Нанорозмірні частки мають унікальні структурні, хімічні, механічні, магнітні, електричні та біологічні властивості. Вони забезпечують успішний транспорт ЛЗ за рахунок таких властивостей, як висока несуча здатність, більш висока стабільність в біологічних рідинах, швидке розчинення, висока розчинність в насичених розчинах, стійкість до осідання, 
здатність перетинати клітинну мембрану, можливість поглинатися клітинами природним чином через адсорбційний ендоцитоз. Ці властивості комплексів з НЧ забезпечують їх більш тривалу циркуляцію, а отже, й потенціал для поліпшення фармакологічного профілю існуючих ЛЗ та можливість застосування нестабільних, високотоксичних та погано розчинних ліків. Так, приєднання до полімерної НЧ діючої речовини дозволяє змінювати іiі розчинність, гідрофобність і проникність, а отже, й забезпечити доставку до цільової ділянки без деградації в шлунково-кишковому тракті, зниження циркулюючого об'єму та активності.

Для прикріплення молекул діючої речовини до НЧ використовуються такі методи, як капсулювання, нековалентне комплексоутврення та кон'югація 3 полімерними носіями, тож нанопристрої, що використовуються у $D D S s$, містять інкапсульовані, поглинені, дисперговані або кон'юговані активні інгредієнти. NanoDDSs діють за допомогою різних механізмів: солюбілізації, таргетування, а також ініційованного вивільнення (triggered release).

Отже, наноносії мають ряд переваг у порівнянні із звичайними Л3:

- захищають діючу речовину від деградації до того, як вона досягне цільового призначення;

- поліпшують їі всмоктування;

- дозволяють контролювати швидкість вивільнення та розподіл активних інгредієнтів по тканинах;

- запобігають їх взаємодії з неушкодженими клітинами, уникаючи побічних ефектів.

Підвищити ефективність доставки наноліків інколи заважають певні біохімічні обмеження, в першу чергу, неефективна розчинність та низька біодоступність деяких інгредієнтів. Приміром вирішення проблеми підвищення біодоступності гідрофобних ліків при пероральному введенні може слугувати система доставки ліків, що самоемульгується (selfemulsifying drug delivery system, SEDDS) - ізотропна суміш природних або синтетичних масел, твердих або рідких поверхнево-активних речовин (ПАР) або одного чи декількох гідрофільних розчинників і співрозчинників/ПАР [5].

Найважливішою характеристикою наноліків є точне націлювання або таргетування (від англ. targeting). Націлювання забезпечується за рахунок того, що структура наноносія дозволяє нанолікам зв'язуватися 3 цільовими рецепторами на клітинній поверхні. Виділяють 2 види таргетування:

1) пасивне - неспецифічне накопичення в ураженій тканині (як правило, ракової);

2) активне або специфічне - селективний транспорт нанопрепарату тільки до конкретних тканини i/aбо клітин.

Розглянемо докладніше обидва види таргетування.

- Пасивна система доставки: при пасивному націлюванні ЛЗ накопичується у місці запалення, або у пухлині. Ефективність таких $D D S s$ прямо залежить від тривалості циркуляції діючої речовини у кровоносній системі. Терапевтичні компоненти (ліки, ферменти, гени, вакцини) приєднуються до НЧ чи наноструктур біогенного (вірусні частки, капсиди) або небіогенного походження, які мають форму контейнера. Нанотехнології також дозволяють створювати вектори, що здатні захищати від деградації білки, ферменти або специфічні поліпептиди, які використовуються у терапевтичному процесі. Наприклад, колоїдосоми (нанокапсули) та ліпосоми можуть утримувати всередині наноструктури активні інгредієнти, які зазвичай не розчиняються в цито-безпечних розчинниках, i адресно доставляти їх до ураженої тканини/органу.

За останні роки розроблено вже три покоління невірусних та вірусних векторів для доставки діючих речовин в клітини [1]:

I - наносфери і нанокапсули (найбільш відомі і доступні);

II - НЧ, вкриті гідрофільними полімерами, такими як ПЕГ, ПЕГіліровані НЧ;

III - комбінація ядра та біорозкладаної полімерної оболонки (ПЕГ) з мембранним розпізнавальним лігандом.

Необхідність виготовлення векторів на основі нуклеїнових кислот з часом призвела до розробки органел-специфічних препаратів, які доставляються безпосередньо всередину клітини (в мітохондрії, лізосоми i т. п.) Ця стратегії виявилася дуже вдалою, тому що внутрішньоклітинний просторовий контроль лікарських НЧ призводить до значного підвищення терапевтичного індексу препарату. 
Здатність вірусів вставляти свою генетичну інформацію в клітини господаря була успішно використана для доставки генів. Вірусні НЧ, котрі використовуються в генній терапії сконструйовані 3 природніх вірусів, у яких більшість патогенних генів замінені на касету терапевтичних генів (при збереженні інфекційних властивостей вірусів). Вірусні капсиди можуть бути змінені шляхом мутагенезу, що дозволяє формувати різні конфігурації задля доставки специфічних генів, ферментів або антимікробних пептидів.

- Активна система доставки: при активному націлюванні до НЧ приєднуються специфічні антитіла, пептиди або аптамери, фрагменти котрих можуть взаємодіяти 3 «мішенями» на клітинах цільових тканин/органів. Основними мішенями є рецептори на клітинних мембранах, ліпідні компоненти клітинної мембрани, антигени або специфічні білки на клітинних поверхнях [8]. Активне націлювання дозволяє доставляти ЛЗ в цільові тканини/органи, що дозволяє знизити необхідну для досягнення терапевтичного результату дозу, зменшити шкідливі наслідки та уникнути небажаних побічних ефектів.

Прикладами активних $D D S$ можуть бути такі нанопристрої, як вуглецеві нанотрубки (найчастіше використовуються для визначення місцезнаходження пухлини і доставки до неї онкологічних препаратів), мікрочіпи, імпланти та зонди, інкапсульовані біологічно локалізованим вкладенням (застосовуються у лікуванні анемії та інфекцій). Поєднання 3 білками також дозволяє створити точні та універсальні гібридні наносистеми.

Особливо активно останні роки розвивається введення наноліків на основі імплантів (implant based drug delivery). Наприклад, для точного дозування терапевтичних з'єднань зі спеціальними профілями доставки (в першу чергу, інсуліну) використовуються імплантовані нанонасоси (nanopumps) для доставки ліків, створені на основі MEMS-чипів. Мікроелектромеханічни системи $(M E M S)$ - це сверхмалі пристрої з резервуарами, приводами, насосами та проточним каналом для точного контролю вивільнення діючої речовини, які можуть бути імплантовані в будь яку тканину чи орган, в тому числі, у мозок. Механізм вивільнення заснований на електрохімічному розчиненні тонких анодних мембран, які покривають мікрорезервуари, заповнені активним інгредієнтом. Це дозволяє контролювати викид одного або декількох ЛЗ. Для виготовлення імплантованих систем використовуються нанопористі матеріали 3 упорядкованою і контрольованою структурою пір, великою площею поверхні і об'ємом пір (наприклад, виготовлені електрохімічним способом нанопористий глинозем і нанотрубчастий титан), моношари, що самозбираються і т. п. Особливо перспективним $є$ використання пористих неорганічних наноматеріалів на основі вуглецю (carbon-based) для доставки генів - gene delivery systems. Хоча тут $є$ певні проблеми. Наприклад, токсичність вуглецевих наноматеріалів, що залежить від їх метаболізму, який, в свою чергу, визначається дозою, формою, хімічним складом поверхні, способом впливу і чистотою.

Крім MEMS-чипів розробляються також біо-чіпи (biochips), виготовлені 3 використанням фотолітографії, наноелектроніки та нових біоматеріалів. Такі архітектури, як решітки та каркаси з нуклеїнових кислот також можуть містити електронні пристрої розміром 3 молекулу або використовуватися для конструювання матеріалів з точними молекулярними конфігураціями. В подальшому вчені очікують створення ДНК-пристроїв (DNA devices), які зможуть реплікуватися, та ДНК-машин (DNA machines) з рухомими частинами у вигляді наномеханічних датчиків, перемикачів і пінцетів.

Наступним кроком вдосконалення nanoDDSs стали «розумні» або інтелектуальні технології доставки ліків (smart DDSs), які забезпечують: 1) вивільнення ЛЗ лише в належному місці з належною швидкістю та 2) не вивільнення (або дуже повільне вивільнення) корисного навантаження до потрапляння в цільові тканини/органи. Точна адресна доставка досягається за рахунок того, що наноносії, які використовуються в smart DDSs, здатні реагувати на специфічні тригери:

- ендогенні: коливання $p H$, рівень гормонів, концентрація ферментів, невеликі біомолекули, рівень глюкози, окислювально-відновний градієнт і т. ін., які пов'язані 3 характеристиками певного захворювання;

- екзогенні: температура, коливання магнітного поля, ультразвук, світло, електричні імпульси і т. ін.

Тригери можуть запускати або посилювати вивільнення активного інгредієнту/діючої речовини в уражених областях, що дозволяє забезпечити: 
а) програмування дії ЛЗ та

б) неінвазивний просторовий і часовий контроль його доставки.

Наприклад, фізичні/хімічні властивості полімерів ефективно трансформуються у відповідь на зміну температури, рівня $p H$ і т. ін., завдяки чому швидкість вивільнення ЛЗ може контролюватися інтенсивністю впливу цих стимулів. На малюнку наведено приклад дії інтелектуальної системи доставки ліків на основі ліпосом для лікування онкологічного захворювання (діюча речовина вивільнюється у відповідь на ультразвукову стимуляцію). Для підвищення точності доставки ліків використовуються наноносії, які здатні реагувати на «гібридні» стимули, наприклад: термо- і рН-чутливі; термо- і світлочутливі; окислювальновідновні і рН-реагуючі; ультразвук- та магнітно-чутливі і т. д.

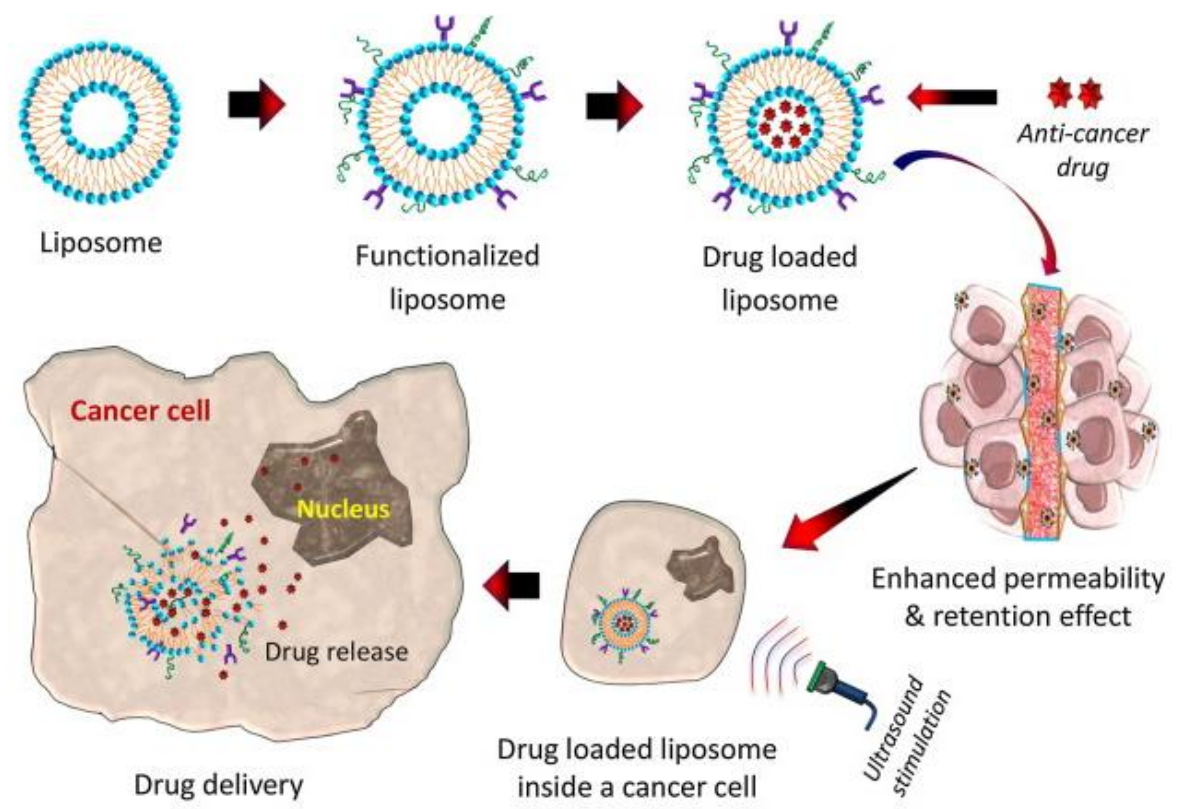

Рис.1. Дія системи доставки ліків на основі ліпосом [6]

До складу типової smart DDSs входять: наноелектромеханічна система (nanoelectromechanical system, NEMS), мікронасоси, мікроосмотичні й нанонасоси, мініатюрні голки, а також датчики та засоби зв'язку для дистанційного керування насосами й контролю перебігу процесів. Біологічні датчики збирають дані від органів і тканин, що дозволяє корегувати графік доставки ліків відповідно до потреб організму.

Застосування $N E M S$ для доставки ліків через біокапсули, мікроголки та мікронасоси допомагає підвищити ефективність фармакотерапії (за рахунок точного i адекватного дозування), а також покращити якість життя пацієнтів (за рахунок зниження доз та зменшення частоти введення ЛЗ, що, в свою чергу, призводить до зниження токсичності).

Висновки. Використання у фармації нанотехнологій допомагає поліпшувати фармакологічні та терапевтичні властивості вже існуючих ЛЗ, розробляти нові ЛЗ із відтворною і передбачуваною кінетикою та вдосконалювати стратегії доставки ліків. Такі особливості НЧ, як малий розмір, індивідуалізована поверхня, поліпшена розчинність i багатофункціональність дають можливість фармацевтам і медикам по-новому взаємодіяти зі складними клітинними функціями. Наприклад, nanoDDSs зможуть поєднуватися з системою комп'ютерного моніторингу для автоматичного регулювання гомеостазу (рівня глюкози в крові, рівня $C a$, рівня оксигенації і т. д.).

Застосування НЧ та наноплатформ для доставки ліків надає ряд переваг у порівнянні зі звичайними $D D S s$. Адресна доставка активного інгредієнта/діючої речовини до цільових клітин або органів покращує їх біорозподіл, модулює імунну відповідь організму, направляє активні молекули на уражені тканини та захищає здорові, зменшує коливання концентрації ЛЗ у цільових органах/тканинах та дозволяє підтримувати його концентрацію протягом більш тривалого часу. За рахунок зниження терапевтично ефективної дози та зниження ризику виникнення системних побічних ефектів підвищується ефективність лікування. Рання 
діагностика та адресна доставка менш токсичних наноліків дозволяють ефективно керувати перебігом важких хронічних захворювань, таких як рак, ВІЛ/СНІД і діабет. Більш висока ефективність та безпечність підвищує вірогідність дотримання пацієнтом схеми лікування, що, в кінцевому підсумку, призводить до зниження витрат на охорону здоров'я.

\section{ЛITEРАТУРА}

1. Boisseau P., Loubaton B.. Nanomedicine, Nanotechnology in medicine. Elsevier, 2011. ffhal-00598930.

2. Brubaker I. O., Bilan O. A., Marchenko-Tolsta K. S. (2020) Review of Modern Approaches to the Development of Nanodrugs. World Science. 5(57), Vol.2. doi: 10.31435/rsglobal_ws/31052020/7081.

3. Global Nanotechnology in Drug Delivery Industry. https://www.reportlinker.com/p05621749/?utm_source=GNW.

4. Grumezescu A. Design of Nanostructures for Versatile Therapeutic Applications. William Andrew. 2018, p690. DOI: 10.1016/C2016-0-04096-2.

5. Gursoy R.N., Benita S. Self-emulsifying drug delivery systems (SEDDS) for improved oral delivery of lipophilic drugs. Biomedicine \& Pharmacotherapy. 2004 Apr; 58(3):173-82. DOI: 10.1016/j.biopha.2004.02.001.

6. Hossen S., Hossain M. K., Basher M.K., Mia M.N.H., Rahman M.T., Uddin M. J. Smart nanocarrier-based drug delivery systems for cancer therapy and toxicity studies: A review. Journal of Advanced Research. 2019, Vol. 15 (1), pp 1-18. https://doi.org/10.1016/j.jare.2018.06.005.

7. Mousa S.A., Bawa R., Audette G.F. The Road from Nanomedicine to Precision Medicine. Jenny Stanford Publishing, 2020, $1208 \mathrm{p}$.

8. Patra J. K., Das G. Nano based drug delivery systems: recent developments and future prospects. Journal of Nanobiotechnology (2018) 16:71. https://doi.org/10.1186/s12951-018-0392-8 